\title{
Mechanism of the Introduction of Exogenous Genes into Cultured Cells Using DEAE-Dextran-MMA Graft Copolymer as a Non-Viral Gene Carrier. II. Its Thixotropy Property
}

Yuki Eshita $^{1 *}$, Junko Higashihara ${ }^{1}$, Masayasu Onishi ${ }^{2}$, Masaaki Mizuno ${ }^{3}$, Jun Yoshida ${ }^{4}$, Tomohiko Takasaki ${ }^{5}$, Hidekatsu Yoshioka ${ }^{6}$, Naoji Kubota ${ }^{7}$ and Yasuhiko Onishi²*

${ }^{1}$ Department of Infectious Disease Control, Faculty of Medicine, Oita University, 1-1 Idaigaoka, Hasama-machi, Yufu-shi, Oita Prefecture 879-5593, Japan ${ }^{2}$ Ryujyu Science Corporation, 39-4 Kosora-cho, Seto-shi, Aichi Prefecture 489-0842, Japan

${ }^{3}$ The Center for Genetic and Regenerative Medicine, Nagoya University Graduate School of Medicine, 65 Tsurumai-cho, Showa-ku, Nagoya-shi, Aichi Prefecture 4668550, Japan

${ }^{4}$ Department of Neurosurgery, Nagoya University Graduate School of Medicine ,65 Tsurumai-cho, Showa-ku, Nagoya-shi, AichiPrefecture466-8550,Japan

${ }^{5}$ Department of Virology 1, National Institute of Infectious Diseases, 1-23-1 Toyama, Shinjyuku-ku, Tokyo 162-8640, Japan

${ }^{6}$ Department of Matrix Medicine, Faculty of Medicine, Oita University, 1-1 Idaigaoka, Hasama-machi, Yufu-shi, Oita Prefecture 879-5593, Japan

${ }^{7}$ Department of Chemistry, Faculty of Medicine, Oita University, 1-1 Idaigaoka, Hasama-machi, Yufu-shi, Oita Prefecture 879-5593, Japan

\begin{abstract}
From comparative investigations regarding the efficiency of introducing exogenous genes into cultured cells using DEAE-dextran and DEAE-dextran-MMA (methyl methacrylate ester) graft copolymer (2-diethylaminoethyl-dextranmethyl methacrylate graft copolymer; DDMC) as a nonviral carrier, we have confirmed that the gene transfection efficiency of DDMC is higher than that of DEAE-dextran. Comparative investigations in which DNA encoding luciferase ( $p$ GL3 control vector; Promega) was introduced into COS-7 cells derived from African green monkey kidney cells with and without the use of an incubator shaker were also carried out using various concentrations of DDMC. Without an incubator shaker, the transfection efficiency results were reversed, namely that the gene introduction efficiency of DDMC was inferior to that of DEAE-dextran. The aqueous solution of the cationic graft-copolymer displays thixotropic properties, which is why a strong shear stress is needed for it to flow and wet the cells. The reaction between DNA and DDMC is thought to be a Michaelis-Menten type complex formation reaction that can be described by the following equation: Complex amount $=\mathrm{K} 1$ (DNA concentration) $($ DDMC concentration). The complex formation reaction is thought to involve Coulomb forces between DDMC and DNA and is also significantly influenced by hydrogen bonding strength along with hydrophobic bonding strength due to the hydrophobicity of the grafted MMA sections.

Regarding the overall transfection rate, the transfection of DNA using DDMC is diffusion controlled and depends on its viscosity and temperature
\end{abstract}

Keywords: Diffusion control; Transfection efficiency; DEAEdextran-MMA graft copolymer; Non-viral gene carrier; Exogenous genes

\section{Introduction}

Gene delivery systems are an important area in the field of genetic nanomedicine [1]. Gene delivery involves the transport of genes, which requires a transport vehicle referred to as a vector. Possible vectors include viral "shells" or lipid spheres (liposomes), which have properties that allow them to be incorporated into host cells. However, viral vectors carry a risk of pathogenicity or immunogenicity because they include a viral shell and part of the viral genome. Liposome vectors are artificial and safe, and are produced by introducing genes into microspheres composed of a lipid bi-layer structure similar to that of the cell membrane. However, they cannot be sterilized by autoclaving as they are unstable at high temperatures. In addition, although favorable results regarding the efficiency of commercial transfection reagents for cationic lipid micelles have been reported, they also cannot be sterilized by autoclaving. Thus, they are not amenable to mainstream use as a non-viral gene carrier. Electrophoresis and microinjection methods are other examples of electrical and physical methods, but they require special devices and technologies.

Cationic polymers are man-made materials and are thus expected to be stable at high temperatures [2]. These compounds have some problems with their cytotoxicity and low transformation rates; however, they have a long history of use as non-viral vectors, and DEAE-dextrans (2-diethylaminoethyl-dextran) are currently being closely investigated because they can be sterilized by autoclaving $[3,4]$.
Recently, we developed copolymers by graft polymerization of methyl methacrylate (MMA) onto DEAE-dextran. These copolymers have hydrophilic and hydrophobic regions, can be sterilized by autoclaving, and are known to be desirable non-viral vectors due to their high transfection efficiency [5-7]. In addition, complexes of DNA and DEAE-dextran-MMA graft copolymer (DDMC) produced by the modification of DEAE-dextran have been reported to demonstrate strong transfection efficiency in COS-7 cells $[9,10]$ and displayed 50fold greater transfection efficiency than DNA complexes with DEAEdextran in HEK293 cells [8].

The DNA/DDMC complex formation reaction is thought to be

*Corresponding authors: Yuki Eshita, Department of Infectious Disease Control, Faculty of Medicine, Oita University, 1-1 Idaigaoka, Hasama-machi, Yufu-shi, Oita Prefecture 879-5593, Japan, Fax: +81-97-586-5701; E-mail: yeshita@oita-u.ac.jp

Yasuhiko Onishi, Ryujyu Science Corporation, 39-4 Kosora-cho, Seto-shi, Aichi Prefecture 489-0842, Japan, Fax:+81-561-84-3227; E-mail: vyx00545@nifty.ne.jp

Received October 07, 2010; Accepted October 28, 2010; Published December 16, 2010

Citation: Eshita Y, Higashihara J, Onishi M, Mizuno M, Yoshida J, et al. (2011) Mechanism of the Introduction of Exogenous Genes into Cultured Cells Using DEAE-Dextran-MMA Graft Copolymer as a Non-Viral Gene Carrier. II. Its Thixotropy Property. J Nanomedic Nanotechnol 2:105. doi:10.4172/2157-7439.1000105

Copyright: @ 2011 Eshita Y, et al. This is an open-access article distributed under the terms of the Creative Commons Attribution License, which permits unrestricted use, distribution, and reproduction in any medium, provided the original author and source are credited. 
Citation: Eshita Y, Higashihara J, Onishi M, Mizuno M, Yoshida J, et al. (2011) Mechanism of the Introduction of Exogenous Genes into Cultured Cells Using DEAE-Dextran-MMA Graft Copolymer as a Non-Viral Gene Carrier. II. Its Thixotropy Property. J Nanomedic Nanotechnol 2:105. doi:10.4172/2157-7439.1000105

directly proportional to the transformation rate, but the complex formation reaction, which is driven by the Coulomb forces between DDMC and DNA, is also significantly influenced by hydrophobic bonding strength as well as hydrogen bonding strength due to the hydrophobicity of the grafted MMA sections. As the amount of complex formed is proportional to the relative light unit (RLU) value, it is thought that the reaction is a Michaelis-Menten type complex formation reaction described by the following equation: Complex amount $=\mathrm{K} 1$ (DNA concentration $)($ DDMC concentration $)$.

However, the details of this mechanism are uncertain. By investigating the incorporation of DNA into cells using quantitative means or visual imaging, it would be possible to clarify this mechanism and design gene delivery systems at the molecular level. This report presents the results of comparative investigations regarding the transfection efficiency of DDMC relative to unmodified DEAE-dextran using COS-7 cells and DNA encoding luciferase-expressing genes.

\section{Materials and Methods}

\section{Reagents}

The pGL3-Control Vector manufactured by Promega was used to carry the DNA encoding luciferase; DEAE-dextran hydrochloride (estimated molecular weight (Mw): 500,000) was manufactured by Sigma-Aldrich Chemical; and DDMC with a graft ratio of $130 \%$ was used at concentrations of 10,20 , and $28.6 \mathrm{mg} / \mathrm{mL}$. The luciferase reagents were from the Bright-Glo Luciferase Kit (Promega), and GloLysis Buffer (Promega) was used as the cell lysis agent.

DEAE-Dextran-MMA graft copolymer: The DEAE-dextranMMA graft copolymer (DDMC) was produced by graft polymerizing methyl methacrylate ester (MMA) on DEAE-dextran using a tetravalent cerium salt [1]. The copolymer was composed of DEAE-dextran as the backbone polymer and PMMA as the branch polymer. A structure with a hydrophilic-hydrophobic microseparated domain was thus formed with the DEAE-dextran forming the hydrophilic domain and the branch polymer PMMA forming the hydrophobic domain.

Definition of copolymer graft ratio: The grafting ratio was defined as the weight ratio of PMMA (branch polymer): DEAE-dextran (backbone polymer). With the DDMC graft polymerization reaction used in the experiments, the PMMA (branch polymer)/DEAE-dextran (backbone polymer) graft ratio was $2.6 \mathrm{~g} / 2 \mathrm{~g}$, or $130 \%$, after the grafting reaction had progressed to completion.

Definition of charge ratio: The charge ratio was defined as the positivity/negativity $(\mathrm{P} / \mathrm{N})$ ratio. In the complex formation reaction between DDMC (N: 1.4\%) and DNA (P: 5.3\%), the compound is formed by ionic bonding (poly-ion complex; PIC), and thus the constituent ratio can be expressed using the weight ratio and charge ratio.

$$
\mathrm{P} / \mathrm{N}(\text { charge ratio })=(\mathrm{y} \times 0.053 \times 14) /(\mathrm{x} \times 0.014 \times 31)
$$

DNA/DDMC $=y / x$ (weight ratio); P: $5.3 \% ; \mathrm{N}: 1.4 \% ; \mathrm{P}$ atomic weight: $14 ; \mathrm{N}$ atomic weight: $31 ; \mathrm{y}$ : amount of DNA; $\mathrm{x}$ : amount of DDMC

\section{Cell transformation}

Test cells: COS-7 African green monkey kidney cells were used, which are CV-1 monkey cells that have been transformed with SV40 to induce a replication initiation point defect and express the SV40 large $\mathrm{T}$ antigen.

Calculation of cell number: A glass pipette was used to remove medium from a $75-\mathrm{cm}^{2}$ flask (Corning) containing COS-7 cells cultured in D-MEM medium containing 10\% FBS. Then, $1 \times$ PBS(-) solution was introduced into a $6-\mathrm{mL}$ flask, the surfaces of the cells were washed, and the $1 \times$ PBS(-) solution was removed. This procedure was repeated twice. Next, $3 \mathrm{~mL}$ of $2 \times 1 \%$ trypsin/EDTA solution were added to release the cells, and $12 \mathrm{~mL}$ of D-MEM medium containing $10 \% \mathrm{FBS}$ were added. The cells were then thoroughly pipetted, and $750 \mu \mathrm{L}$ of $1 \times$ PBS(-) solution and $200 \mu \mathrm{L}$ of $0.5 \%$ Trypan Blue were immediately added to $50 \mu \mathrm{L}$ of the COS-7 cell suspension, before the cells were thoroughly agitated, and live cells were counted using a hemocytometer. A 96-well microtiter plate was used, and the cells were added to each well at a cell count of $2 \times 10^{4} /$ well. To prevent drying, $100 \mu \mathrm{L} /$ well of D-MEM medium were added to the empty wells of the microtiter plate. Subsequently, the microtiter plate containing COS-7 cells was cultured for one day under $37^{\circ} \mathrm{C}$ and $5 \% \mathrm{CO}_{2}$.

Production of transfection solutions: Plasmid DNA $(0.05 \mu \mathrm{g}$; pGL3-Control Vector) encoding luciferase was diluted with $2.6 \mu \mathrm{L}$ of $1 \times$ PBS (-) solution in a sterile tube, and $0.14 \mu \mathrm{L}$ of DEAE-dextran or DDMC was added and stirred thoroughly to prepare the solutions.

Transfection method: COS-7 cells were cultured overnight, and then the culture solution was removed from each well of the 96-well microtiter plate. Next, the cells were washed twice with $100 \mu \mathrm{L}$ of $1 \times$ PBS (-) solution, and $2.79 \mu \mathrm{L}$ of transfection solution were added to the COS-7 cells in each well. The 96-well microtiter plate was then gently but sufficiently agitated using an incubator shaker during culture so that the solution was well circulated. The microtiter plate was incubated for $30 \mathrm{~min}$ at $37^{\circ} \mathrm{C}$ while being swirled every $5 \mathrm{~min}$. Subsequently, $28.8 \mu \mathrm{L} /$ well D-MEM medium containing $10 \%$ FBS were added to the microtiter plate, and the plate was incubated for $2.5 \mathrm{~h}$ at $37^{\circ} \mathrm{C}$. Then, the $\mathrm{D}$-MEM medium was removed, and $100 \mu \mathrm{L}$ of fresh D-MEM medium containing $10 \%$ FBS were added and incubated for 24 to $96 \mathrm{~h}$ at $37^{\circ} \mathrm{C}$.

Emission measurement: After $24 \mathrm{~h}$ (or 48, 72, or 96 h), the plate containing the incubated COS-7 cells (and the transfection solution) was removed from the incubator, the medium was removed, and the cells were rinsed with $50 \mu \mathrm{L} /$ well of $1 \times$ PBS(-) solution. Next, $25 \mu \mathrm{L} /$ well Glo Lysis Buffer were added, and the culture plate was swirled. After $5 \mathrm{~min}, 25 \mu \mathrm{L} /$ well Bright-Glo Luciferase reagent were added, and emission measurements were carried out after 2 min using a SPECTRA Fluor Plus (Tekan) and the LS-PLATEmanager 2001 software (Wako Pure Chemical) to obtain RLU values. The measurement conditions were set to a gain of 150 and the maximum integration time. The Turner light unit (TLU) values used in this report represent the sample RLU value/control RLU value.

Calculation of RLU values: To calculate the RLU values of the samples, the mean RLU values of two wells in the 96-well microtiter plate were used, and the mean RLU value was determined from two parallel sample runs.

Sterilization agents: No antibiotic or antifungal agents were added to the D-MEM medium containing 10\% FBS used to culture the cells. However, after $2.5 \mathrm{~h}$ incubation and the addition of the transfection solution, D-MEM medium containing 10\% FBS and antibioticantifungal agent (penicillin/streptomycin/amphotericin B; Invitrogen) was used as the culture solution.

DNase decomposition testing: A 1-mL sample of DNA solution $(10 \mathrm{mg} / \mathrm{mL})$ derived from salmon sperm and $1 \mathrm{~mL}$ of $0.005 \%$ toluidine blue solution ( $\mathrm{pH} \mathrm{7)}$ were allowed to react, to which $1 \mathrm{~mL}$ of DEAEdextran solution $(10 \mathrm{mg} / \mathrm{mL})$ or $1 \mathrm{~mL}$ of DDMC with an equivalent charge $(28.6 \mathrm{mg} / \mathrm{mL})$ was added and allowed to react to reduce the deposition of the PIC complex. The solutions were then allowed to pass 
Citation: Eshita Y, Higashihara J, Onishi M, Mizuno M, Yoshida J, et al. (2011) Mechanism of the Introduction of Exogenous Genes into Cultured Cells Using DEAE-Dextran-MMA Graft Copolymer as a Non-Viral Gene Carrier. II. Its Thixotropy Property. J Nanomedic Nanotechnol 2:105. doi:10.4172/2157-7439.1000105

Page 3 of 8

through \#5 filter paper (Advantech) and into a test tube. Next, $4 \mathrm{~mL}$ of distilled water were added, followed by $0.01 \mathrm{~mL}(0.01 \mathrm{mg})$ of RQ1 RNase-Free DNase and $0.1 \mathrm{~mL}$ of $10 \times$ PBS(-) buffer solution. DNA decomposition was allowed to occur at $30^{\circ} \mathrm{C}$, and the absorption of the toluidine blue released into the supernatant liquid as a result of this series of reactions was then measured at $633 \mathrm{~nm}$.

\section{Results}

\section{Transfection}

We used 96-well microtiter plates, and the optimal method for transfecting a complex of pGL3-Control Vector DNA and its carrier into COS-7 cells was investigated. The results are shown in Figure 1.

In Figure 2, the transfection efficiency of DDMC is also shown using HEK293cells and A pCAGGS/LacZ, which expresses $\beta$-galactosidase in eukaryotic cells.

The transfection efficiency of DDMC (graft ratio: 130\%) shown in Figure 1 and the TLU values for DDMC at a concentration of $10.0 \mathrm{mg} /$ $\mathrm{mL}$ were lower than for those for DEAE-dextran, but when the DDMC concentration was increased, the transfection efficiency of DDMC became higher than that of DEAE-dextran.

Figure 2 confirms that DDMC displayed a higher transfection efficiency than DEAE-dextran hydrochloride and that the transfection efficiency and the efficiency increase were dependent on the DDMC concentration.

The results of Figure 2 were very similar to those of Figure 1. In both the experiments using COS-7 cells and those using HEK293cells a strong shear stress was required to allow the transfection solution to flow and wet the cells.

In Figure 1, the TLU values were approximately equivalent at a concentration of $20.0 \mathrm{mg} / \mathrm{mL}$, but the transfection efficiency of DDMC was_2-fold higher than that of DEAE-dextran at a concentration of $28.6 \mathrm{mg} / \mathrm{mL}$. The fact that the transfection efficiency increased in a concentration-dependent manner may have been due to the low cellular toxicity of the complex formed between DDMC and DNA.

Transfection efficiency also increased in a concentration-dependent manner in Figure 2.

\section{Transfection at low shear stress}

During transfection the aqueous solution of the cationic graftcopolymer displayed thixotropic properties, which is why a strong shear stress was needed to allow the solution to flow and wet the cells.

Transfection at low shear stress was evaluated by adding the mixture of DNA and the cationic graft-copolymer to COS-7 cells and swirling the plate in the absence of an incubator shaker.

Figure 3 shows the opposite result to Figures 1 and 2; i.e., that TLU value decreased in a concentration-dependent manner as follows: $9.8 \mathrm{mg} / \mathrm{ml}(0 \%)>10 \mathrm{mg} / \mathrm{ml}>120 \mathrm{mg} / \mathrm{ml}>28.6 \mathrm{mg} / \mathrm{ml}$.

As the aqueous solution of DDMC displayed thixotropic properties, a strong shear stress is required for it to flow and wet cells. If the shear stress applied is not enough strong, the viscosity of the solution increases in a concentration-dependent manner as follows: $9.8 \mathrm{mg} / \mathrm{ml}$ $(0 \%)<10 \mathrm{mg} / \mathrm{m}<120 \mathrm{mg} / \mathrm{ml}<28.6 \mathrm{mg} / \mathrm{ml}$.

The Stokes-Einstein (SE) equation is as follows:

$\mathrm{D} \propto \mathrm{kT} / \eta$ where $\mathrm{D}$ is the diffusion coefficient $\left(\mathrm{cm}^{2} / \mathrm{sec}\right), \mathrm{T}$ is temperature , and $\eta$ is viscosity ( $\mathrm{Pa} \mathrm{s})$.

From the SE equation, the diffusion coefficient decreases in a concentration-dependent manner as follows: $9.8 \mathrm{mg} / \mathrm{ml}(0 \%)>10 \mathrm{mg} /$ $\mathrm{ml}>120 \mathrm{mg} / \mathrm{ml}>28.6 \mathrm{mg} / \mathrm{ml}$, which supports the result shown in Figure 3.

Therefore, an incubator shaker that induces a strong shear stress should be used to obtain a higher transfection efficiency.

However, this experiment shows that the transfection reaction is diffusion controlled and depends on the viscosity of the transfection reagent and the incubation temperature.

The relationship between the weight ratio of DNA/DDMC and transfection at low shear stress and low concentration.

Transfection efficiency was then evaluated in an experiment in which the amount of DNA (pGL3-Control) was fixed at $0.075 \mu \mathrm{g} /$ well, $0.15 \mu \mathrm{g} / \mathrm{well}$, or $0.3 \mu \mathrm{g} / \mathrm{well}$ and the amount of DDMC was changed from $0 \mu \mathrm{g} /$ well to $15 \mu \mathrm{g} /$ well. In these experiments, the DNA concentration was diluted 4 to 16 fold with D-MEM medium compared with the previous experiments, and no incubator shaker was used.

The amount of DNA was assumed to be constant $(0.075 \mu \mathrm{g}, 0.15 \mu \mathrm{g}$, or $0.3 \mu \mathrm{g})$, and the amount of DDMC was changed from $0-15 \mu \mathrm{g}$, and we examined which combination gave the highest transfection efficiency.

The optimal incubation time changed from 48 to 120 hours as the amount of DNA increased, and the optimal weight ratio of DNA/DDMC was 80,80 , and 40 for $0.075 \mu \mathrm{g}, 0.15 \mu \mathrm{g}$, and $0.3 \mu \mathrm{g}$ of DNA, respectively. For DEAE-dextran $(\mathrm{x})$, it has been reported that the optimal $\mathrm{y} / \mathrm{x}$ weight ratio with respect to DNA (y) is $1 / 50$ [15].

Under the above conditions, transfection efficiency was generally low because the DNA had been diluted 4 to 16 fold with D-MEM medium and no incubator shaker was used.

Everything can be considered because of the diffusion control by the viscosity that is non- Newtonian fluid.

\section{Discussion}

\section{Charge ratio $(\mathrm{P} / \mathrm{N}$ ratio $)$}

When considering transfection efficiency, the charge ratio $(\mathrm{P} / \mathrm{N})$ of each sample is important, as is the concentration. It is thus necessary to equalize $\mathrm{P} / \mathrm{N}$ values when comparing the $\mathrm{RLU}$ values of DEAE-dextran and DDMC. For example, the percentage of nitrogen in DEAE-dextran is $3.3 \%$, and the percentage phosphorus in DNA is about $5.33 \%$. The $\mathrm{P} / \mathrm{N}$ values shown in Figures 1, 2, and 3 were thus obtained.

With regard to the dependence of the amount DNA transferred into the cells on the $\mathrm{P} / \mathrm{N}$ ratio, it would appear that a comparison can be made between the RLU values of DEAE-dextran (graft ratio 0\%) and DDMC (graft ratio 130\%) at similar sample $\mathrm{P} / \mathrm{N}$ values. In other words, a $\mathrm{P} / \mathrm{N}$ value of 0.021 was found for DDMC (graft ratio: $130 \%$ ) at a concentration of $28.6 \mathrm{mg} / \mathrm{mL}$ and the $\mathrm{P} / \mathrm{N}$ value for DEAE-dextran

\begin{tabular}{|l|c|}
\hline & P/N ratio \\
\hline DEAE-dextran (grafting rate: $0 \%$ ) & 0.026 \\
\hline DEAE-dextran-MMA graft copolymer (grafting rate: $130 \%$ ) \\
\hline DDMC $28.6 \mathrm{mg} / \mathrm{mL}$ & 0.021 \\
\hline DDMC $20.0 \mathrm{mg} / \mathrm{mL}$ & 0.030 \\
\hline DDMC $10.0 \mathrm{mg} / \mathrm{mL}$ & 0.060 \\
\hline
\end{tabular}

Table 1: Charge ratios (P/N) of DEAE-dextran-MMA graft copolymer (DDMC) and DEAE-dextran to DNA. 
Citation: Eshita Y, Higashihara J, Onishi M, Mizuno M, Yoshida J, et al. (2011) Mechanism of the Introduction of Exogenous Genes into Cultured Cells Using DEAE-Dextran-MMA Graft Copolymer as a Non-Viral Gene Carrier. II. Its Thixotropy Property. J Nanomedic Nanotechnol 2:105. doi:10.4172/2157-7439.1000105

was nearly the same at 0.026 ; therefore, it was concluded that the charge ratios of both DEAE-dextran (graft ratio: 0\%) and DDMC (graft ratio $130 \%)$ are approximately equivalent (Table 1). When transfection efficiency (TLU value) was compared based on these two RLU values, the TLU value at a DDMC concentration of $28.6 \mathrm{mg} / \mathrm{mL}$ was about 2 -fold higher than that of DEAE-dextran, and this was thought to be due to micelle micro-formation resulting from the hydrophilic-hydrophobic microseparated domain of DDMC. Nevertheless, in the absence of an incubator shaker, the results were reversed (Figure 3), namely that the gene introduction efficiency of DDMC was inferior to that of DEAEdextran, as the aqueous solution of DDMC has thixotropic properties and so requires a strong shear stress to be able to flow and wet the cells.

In the transfection experiments, both DDMC and DEAE-dextran (graft ratio: 0\%) gave high RLU values compared with the commerciallyavailable product PolyFect (QIAGEN) [11], a result that was obtained in preliminary testing using COS-7 cells. This suggests that there is a fairly large variation in efficiency depending on the transfection conditions such as reagent amount, etc.

\section{Expression time}

When comparing the luciferase protein expression times of DDMC and DEAE-dextran in COS-7 cells (Figure 1), at $24 \mathrm{~h}$ the luciferase activity of both DEAE-dextran (graft ratio: $0 \%$ ) and DDMC (graft ratio: $130 \%, 28.6 \mathrm{mg} / \mathrm{mL}$ ) were low. During transfection under low shear stress, the luciferase activity of DDMC at $24 \mathrm{~h}$ after transfection was low, as shown in Figure 3. Although the luciferase expression of DDMC was confirmed to be extremely high after $48 \mathrm{~h}$ in the experiment shown Figure 1 and at low concentrations (Figures 4, 5, and 6), it remained low during transfection under low shear stress (Figure 3). Although DDMC (graft ratio: 130\%) displayed low expression after $24 \mathrm{~h}$ with COS-7 cells

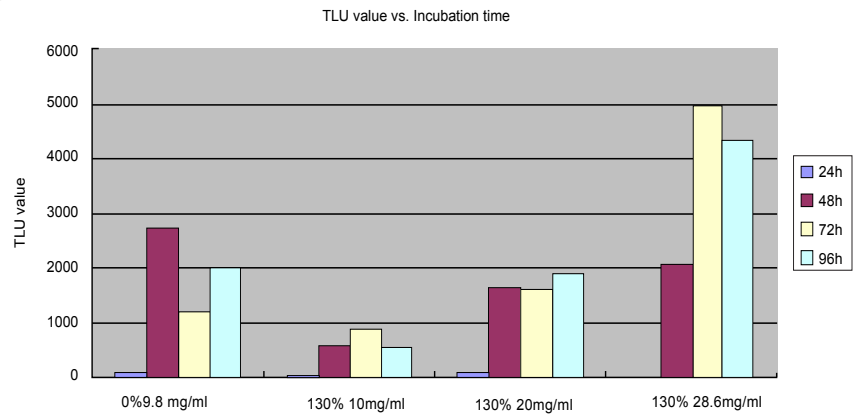

Figure 1: Transfection of COS-7 cells with DEAE-dextran (sample 1) and DEAE-dextran-MMA graft copolymer. The grafting rate is $130 \%$ for samples 2,3 , and 4 at $10 \mathrm{mg} / \mathrm{mL}$, sample 3 at $20 \mathrm{mg} / \mathrm{mL}$, and sample 4 at $28.6 \mathrm{mg} / \mathrm{mL}$.

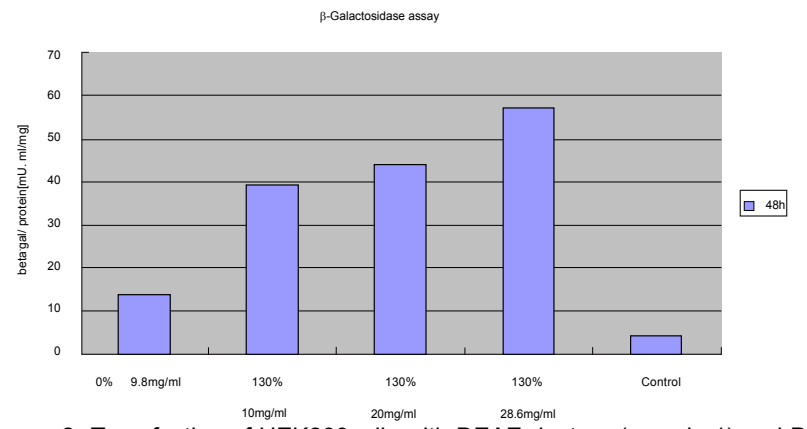

Figure 2: Transfection of HEK293cells with DEAE-dextran (sample 1) and DEAE-dextran-MMA graft copolymer. The grafting rate is $130 \%$ for samples 2,3 , and 4 .

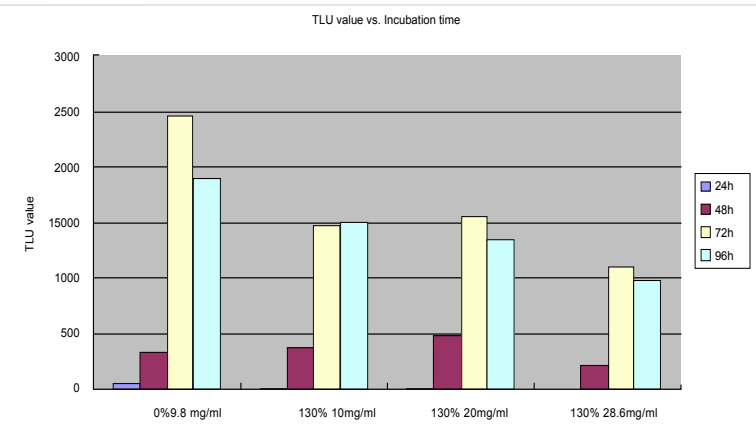

Figure 3: Transfection of COS-7 cells at low shear stress with DEAE-dextran (sample 1) and DEAE-dextran-MMA graft copolymer. The grafting rate was $130 \%$ for samples 2,3 , and 4 .

in both Figures 1 and 3, there was a trend towards higher RLU values over time (see 72 and $96 \mathrm{~h}$ in Figures 1 and 3). This was thought to be due to the fact that the DDMC-DNA complex is comparatively stable, and thus, a long period of time is required for its transport into the cell nucleus, and DNA release and expression.

The difference in the expression times of DEAE-dextran and DDMC were discussed above, but it was determined that the optimal expression time for DDMC was $72 \mathrm{~h}$ (Figures 1 and 3).

When the transfection efficiencies of DEAE-dextran (graft ratio: $0 \%$ ) and DDMC were compared in transfection experiments carried out using HEK293 cells, similar results to those shown in Figure 2 were obtained with DDMC (graft ratio: 130\%) [5-10].

However, in our experiments (Figure 1), the concentrations were limited to $28.6 \mathrm{mg} / \mathrm{mL}$ and $20.0 \mathrm{mg} / \mathrm{mL}$, and the expression produced at a concentration of $10.0 \mathrm{mg} / \mathrm{mL}$ was lower than that observed with DEAE-dextran. This is suggested to be due to the absolute amount of DNA transported in this experimental system due to DDMA being a non-Newtonian fluid rather than being related to DEAE-dextran or DDMC cellular toxicity.

In addition, considering the optimal value for expression time discussed above, it was thought that DEAE-dextran and DDMC have different transfection mechanisms. This is indicated by the fact that almost no luciferase protein was expressed in COS-7 cells at $24 \mathrm{~h}$ after transfection, especially when DDMC was used (graft ratio: 130\%, 28.6 $\mathrm{mg} / \mathrm{mL}$ ), which was not the case for DEAE-dextran (graft ratio: $0 \%$ ). It was therefore thought that DNA condensation may play an important role in transfection efficiency [12,13] and that the dissociation conditions of the complexes formed between DNA and DDMC or DEAE-dextran in the nucleus also may differ.

\section{DNase protective activity}

One objective purpose of using DDMC is that a stable complex is formed with DNA. Specifically, the complex formed between DEAEdextran and DNA is not very stable, and decomposition by intracellular dextransucrase is thought to occur after its transport into the cell, thus decreasing its transfection efficiency. In addition, the DEAE-dextran concentration cannot be increased due to its cellular toxicity.

DDMC is obtained by graft-polymerizing a vinyl monomer onto DEAE-dextran in order to stabilize the complex it forms with DNA. It is thought that this stabilization process delays luciferase expression [13].

As a result of obtaining higher expression levels with DDMC (Figure 1), it was also thought that the cellular toxicity of DDMC is lower than that of DEAE-dextran. Thus, the protective effects of DDMC 
Citation: Eshita Y, Higashihara J, Onishi M, Mizuno M, Yoshida J, et al. (2011) Mechanism of the Introduction of Exogenous Genes into Cultured Cells Using DEAE-Dextran-MMA Graft Copolymer as a Non-Viral Gene Carrier. II. Its Thixotropy Property. J Nanomedic Nanotechnol 2:105. doi:10.4172/2157-7439.1000105

against DNase were investigated in vitro. As a result, we found (Figure 7) that the decomposition of DNA by DNase progressed from the start of the experiment in the case of DEAE-dextran/DNA, and a large quantity of toluidine blue was released, resulting in a significant change in absorption [14]. In the case of DDMC/DNA, the decomposition of DNA progressed slowly, and the change in absorption was extremely small. A significant difference was thus seen between the protective effects of DEAE-dextran and DDMC against DNase. The action of DDMC in protecting against DNase decomposition was dramatically increased in comparison to that of DEAE-dextran, and this is thought to be one of the causes of its increased transfection efficiency.

\section{Complex formation reaction mechanisms}

The difference in the protein expression of DNA transported in complex with DDMC or DEAE is thought to be caused by their different complex formation reactions, particularly when their concentrations are very low. In these DNA and DDMC complex formation reactions, the hydrophobic bonding force is strongly influenced by the hydrophobicity of the grafted MMA regions, as well as Coulomb forces and hydrogen bonding forces, thus giving rise to a reversible equilibrium relationship. The Michaelis-Menten complex formation reaction is thought to occur as follows:

Formed complex amount $=\mathrm{K} 1(\mathrm{DNA}$ concentration $)(\mathrm{DDMC}$ concentration)

The amount of complex formed is proportional to the RLU value. The reaction in which the complex between DEAE-dextran and DNA is

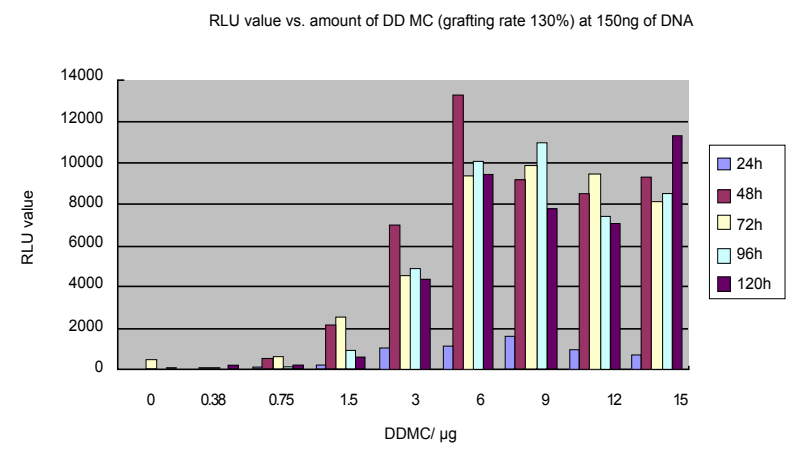

Figure 4: Transfection of COS-7 cells using low shear stress and a low DEAEdextran-MMA graft copolymer concentration. The grafting rate was $130 \%$ for the DDMC sample. The amount of DNA was $75 \mathrm{ng}$, and the concentration of DDMC was changed from $0 \mu \mathrm{g} /$ well to $15 \mu \mathrm{g} /$ well.

RLU value vs. amount of DD MC (grafting rate $130 \%$ ) at 150ng of DNA

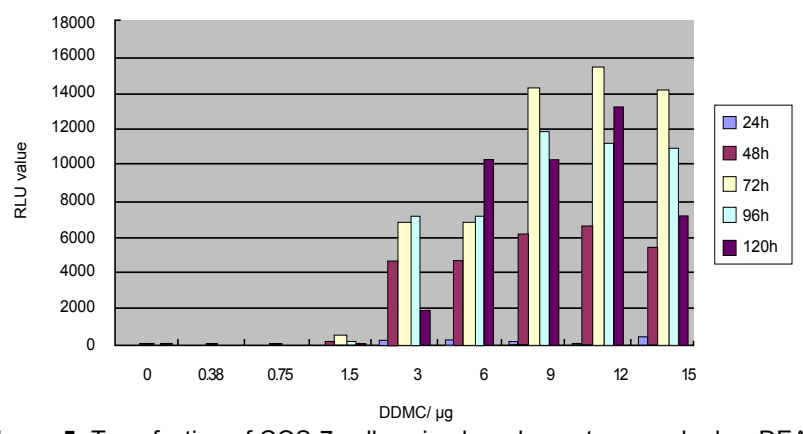

Figure 5: Transfection of COS-7 cells using low shear stress and a low DEAEdextran-MMA graft copolymer concentration. The grafting rate was $130 \%$ for the DDMC sample. The amount of DNA was $150 \mathrm{ng}$, and the concentration of DDMC was changed from $0 \mu \mathrm{g} /$ well to $15 \mu \mathrm{g} /$ well.

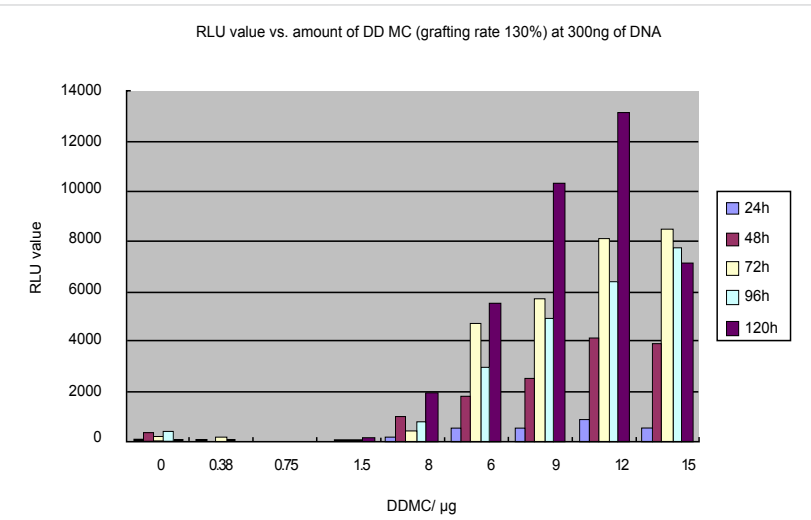

Figure 6: Transfection of COS-7 cells using low shear stress and a low DEAEdextran-MMA graft copolymer concentration. The grafting rate was $130 \%$ for the DDMC sample. The amount of DNA was $300 \mathrm{ng}$, and the concentration of DDMC was changed from $0 \mu \mathrm{g} /$ well to $15 \mu \mathrm{g} /$ well.

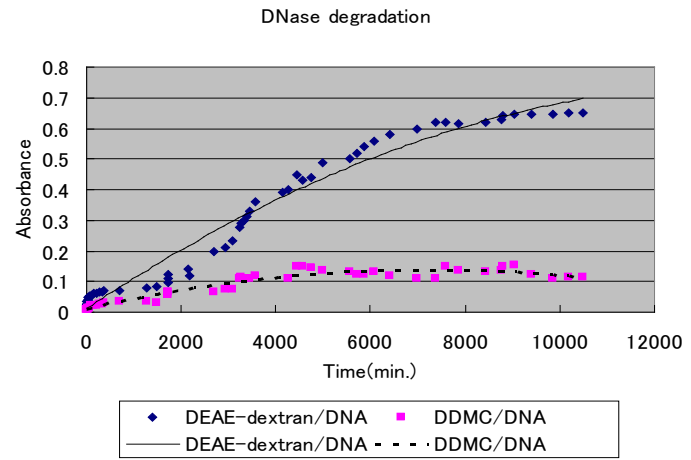

Figure 7: DNase degradation times for the complexes formed between foreign DNA and DEAE-dextran-MMA graft copolymer or DEAE-dextran, respectively. DNase I degrades both double-stranded and single-stranded DNA endonucleolytically, producing 3'-OH oligonucleotides. Toluidine blue (TB) was isolated from the water after degradation, as the DNA was stained with TB. This graph shows the absorbance of the TB isolated from the DNA in each sample measured with a spectrophotometer.

formed is nearly non-reversible because it depends mostly on Coulomb forces, and the reaction is first-order with respect to DEAE-dextran concentration. The reaction can be expressed as follows:

Complex formation amount $=\mathrm{K} 2$ (DEAE-dextran concentration)

Figure 4 shows the conditions that produced high transfection efficiencies when the transfection solution was diluted 10.9 times, the amount of DNA was held constant at $0.075 \mu \mathrm{g}$, and the amount of DDMC was varied from 0 to $15 \mu \mathrm{g}$.

In contrast to the results shown in Figure 1, the RLU values of DDMC produced at the very low concentrations shown in Figures 4, 5 , and 6 are very low, and the RLU values of DEAE-Dextran produced at these very low concentrations are higher than those of DDMC. The RLU value is thought to be directly related to the rate of complex formation. The reason why the complexes between DNA and DDMC demonstrated very low RLU values in Figures 4, 5, and 6 is that DDMC displays thixotropic properties and these experiments were performed in the absence of a strong shear stress.

As the complex formed between DNA and DDMC is thought to occur via Michaelis-Menten complex formation, its formation rate is very low at low concentrations according to Eq.(2). 
Citation: Eshita Y, Higashihara J, Onishi M, Mizuno M, Yoshida J, et al. (2011) Mechanism of the Introduction of Exogenous Genes into Cultured Cells Using DEAE-Dextran-MMA Graft Copolymer as a Non-Viral Gene Carrier. II. Its Thixotropy Property. J Nanomedic Nanotechnol 2:105. doi:10.4172/2157-7439.1000105

The complex formation capacity is thought to give rise to a reversible equilibrium relationship, which can be expressed as a Michaelis-Menten equation:

$$
\begin{aligned}
& {[\mathrm{E}]+[\mathrm{S}] \stackrel{\mathrm{Km}}{\rightleftarrows}[\mathrm{ES}]} \\
& {[\mathrm{E}][\mathrm{S}] /[\mathrm{ES}]=\mathrm{Km}}
\end{aligned}
$$

In this case, $[\mathrm{E}]$ is used to represent the concentration of DEAEdextran or DDMC, and [S] is used to represent the DNA concentration. Taking the initial DEAE-dextran or DDMC concentration as $\left[\mathrm{E}_{0}\right]$, then:

$$
[\mathrm{E}]=\left[\mathrm{E}_{0}\right]-[\mathrm{ES}]
$$

Inserting these values, the complex concentration becomes:

$$
[\mathrm{ES}]=\left[\mathrm{E}_{0}\right][\mathrm{S}] /(\mathrm{Km}+[\mathrm{S}])
$$

For DDMC, the Coulomb forces are small (low affinity between $\mathrm{E}$ and $\mathrm{S}$, and the fact that $[\mathrm{S}]$ is small has a direct influence on the formation of the complex). As $\mathrm{Km}$ increases, the complex becomes unstable, and $[\mathrm{S}]$ is negligible relative to $\mathrm{Km}$. According to this formula, assuming $\mathrm{Km}>>[\mathrm{S}]$, the complex concentration becomes:

$$
[\mathrm{ES}]=\left[\mathrm{E}_{0}\right][\mathrm{S}] / \mathrm{Km}
$$

This is the case for DDMC, and it is highly likely that the formation of the complex is strongly influenced by the concentration conditions. In other words, it is thought that a very low DDMC concentration will have a significant influence on complex formation.

Conversely, in the case of DEAE-dextran, complex formation is stabilized when the Coulomb forces are large (high affinity between $\mathrm{E}$ and $\mathrm{S}$, and the fact that $[\mathrm{S}]$ is small does not have a direct influence on the formation of the complex). As $\mathrm{Km}$ is small, $\mathrm{Km}$ thus conversely becomes negligible in comparison to $[\mathrm{S}]$. Assuming that $\mathrm{Km}<<[\mathrm{S}]$, the complex concentration similarly becomes:

$$
[\mathrm{ES}]=\left[\mathrm{E}_{0}\right]
$$
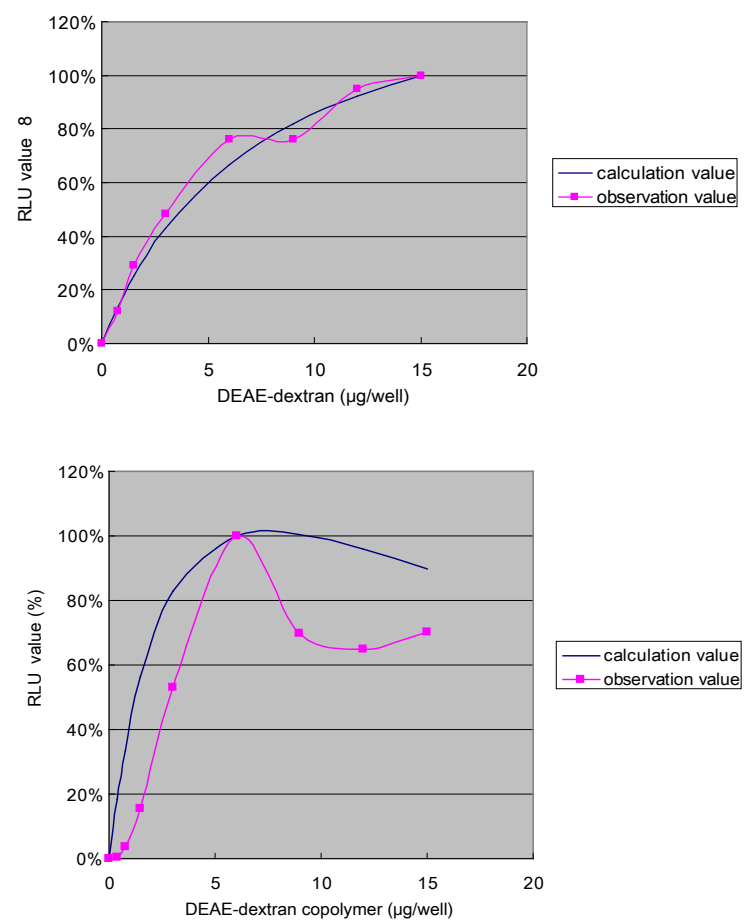

Figure 8: Transfection of COS-7 cells with samples of DEAE-dextran and DEAE-dextran-MMA graft copolymer (grafting rate: $130 \%$ ) containing $0.075 \mu \mathrm{g}$ of DNA. The maximum luciferase expression observed in each experiment was set at $100 \%$.
RLU value vs. amount of DDMC with DNA 75ng, 150ng, and 300ng, at $48 \mathrm{~h}$

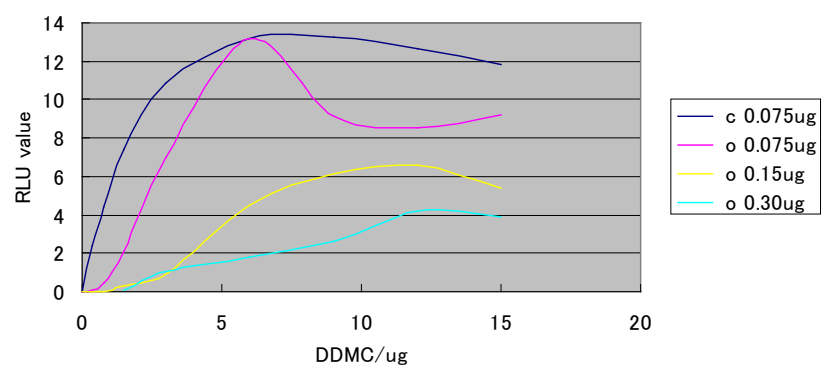

Figure 9: Transfection of COS-7 cells with samples of DEAE-dextran-MMA graft copolymer (grafting rate: $130 \%$ ) containing $0.075 \mu \mathrm{g}, 0.150 \mu \mathrm{g}$, or $0.30 \mu \mathrm{g}$ of DNA in comparison with the value calculated for DEAE-dextran-MMA copolymer samples containing $0.075 \mu \mathrm{g}$. DNA.

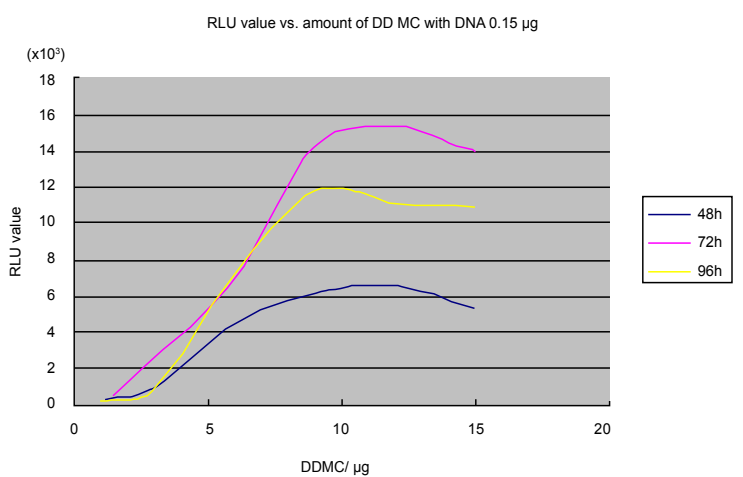

Figure 10: Transfection of COS-7 cells with samples of DEAE-dextran-MMA graft copolymer (grafting rate: $130 \%$ ) containing $0.15 \mu \mathrm{g}$ of DNA for an incubation time of $48 \mathrm{~h}, 72 \mathrm{~h}$, or $96 \mathrm{~h}$.

This indicates that complex formation is proportional to the DEAEdextran concentration. In other words, it is likely that the DEAEdextran concentration has no significant influence on quantitative complex formation, even when the concentration is very low.

However, the Michaelis-Menten complex formation reaction between DDMC and DNA is thought to be significantly influenced by concentration. The relationship is expressed in Figure 8 using K1 $=1.055 \times 10^{-7}(\mu \mathrm{g} /$ well $)$ and $\mathrm{K} 2=1.626 \times 10^{-5}(\mu \mathrm{g} /$ well $)$, which were determined at the maximum RLU values and by normalizing the RLU values by defining the maximum experimental values as $100 \%$. Figure 8 shows a good correspondence between DEAE-dextran and DDMC under conditions of $48 \mathrm{~h}$ and $0.075 \mu \mathrm{g}$ of DNA. Using $0.075 \mu \mathrm{g}$ DNA and $0.75 \mu \mathrm{g}$ DDMC, with a total volume of $30 \mu \mathrm{L}$ D-MEM not containing FBS, the DNA concentration is $0.075 \mu \mathrm{g} / 30 \mu \mathrm{L}$ or $0.0025 \mu \mathrm{g} / \mathrm{mL}$, and the DDMC concentration is $0.75 \mu \mathrm{g} / 30 \mu \mathrm{L}$ or $0.025 \mu \mathrm{g} / \mu \mathrm{L}$. Although the vertical axis in Figure 8 (RLU) should normally display the amount of complex formed, as the amount of complex formed is proportional to the RLU, the reaction mechanisms may be understood to be analogous if the trends shown in the figure are similar. As shown in Figures 9 and 10 , the transfection of COS-7 cells with samples of DDMC supports our assertion that this is a Michaelis-Menten complex formation reaction.

Figure 9 shows the transfection of COS-7 cells with samples of DDMC (grafting rate: $130 \%$ ) containing $0.075 \mu \mathrm{g}, 0.150 \mu \mathrm{g}$, or $0.30 \mu \mathrm{g}$ of DNA in comparison with the values calculated for $0.075 \mu \mathrm{g}$ of DNA using Eq.2 at $48 \mathrm{~h}$. The relationships between RLU values and the amounts of DDMC for $0.075 \mu \mathrm{g}, 0.150 \mu \mathrm{g}$, or $0.30 \mu \mathrm{g}$ of DNA are also in 
Citation: Eshita Y, Higashihara J, Onishi M, Mizuno M, Yoshida J, et al. (2011) Mechanism of the Introduction of Exogenous Genes into Cultured Cells Using DEAE-Dextran-MMA Graft Copolymer as a Non-Viral Gene Carrier. II. Its Thixotropy Property. J Nanomedic Nanotechnol 2:105. doi:10.4172/2157-7439.1000105

Page 7 of 8

good accordance with the predicted values. The degree of transfection shown in Figure 9 is as follows: $0.075 \mu \mathrm{g}>0.150 \mu \mathrm{g}>0.30 \mu \mathrm{g}$ of DNA and depended on the DDMC concentration, and the DDMC concentration at which transfection peaked is as follows: $0.075 \mu \mathrm{g}<0.150 \mu \mathrm{g}<0.30 \mu \mathrm{g}$ of DNA.

Figure 10 shows the transfection of COS-7 cells with samples of DDMC (grafting rate: $130 \%$ ) containing $0.15 \mu \mathrm{g}$ of DNA for incubation times of $48 \mathrm{~h}, 72 \mathrm{~h}$, or $96 \mathrm{~h}$.

The relationships among RLU values, the amount of DDMC, and with the incubation time are also good accordance with the calculated values.

The degree of COS-7 cell transfection shown in Figure 10 is as follows: $72 \mathrm{~h}>96 \mathrm{~h}>48 \mathrm{~h}$ incubation time.

We found that $48 \mathrm{~h}$ is the optimal incubation time for DEAE-dextran at very low concentrations of DNA. However, the optimal amounts of DNA when incubating very low concentrations of DDMC for $48 \mathrm{~h}, 72 \mathrm{~h}$, and $120 \mathrm{~h}$ are $0.075 \mu \mathrm{g}, 0.150 \mu \mathrm{g}$, and $0.30 \mu \mathrm{g}$ of DNA, respectively.

These phenomena can be considered to be due to the viscosity of DDMC as well as its DNase protective activity, which is derived from its hydrophilic-hydrophobic micro-separated domain.

\section{Hydrophobic bonding contribution by the hydrophilic- hydrophobic micro-separated domain}

In the complex formation reaction that occurs between DEAEdextran and DNA, Coulomb forces are understood to be the primary factor in the poly-ion complex (PIC) reaction, and thus experiments were carried out to compare the DDMC-DNA complex formation reaction with that of DEAE-dextran $[3,4]$. The DDMC-DNA complex

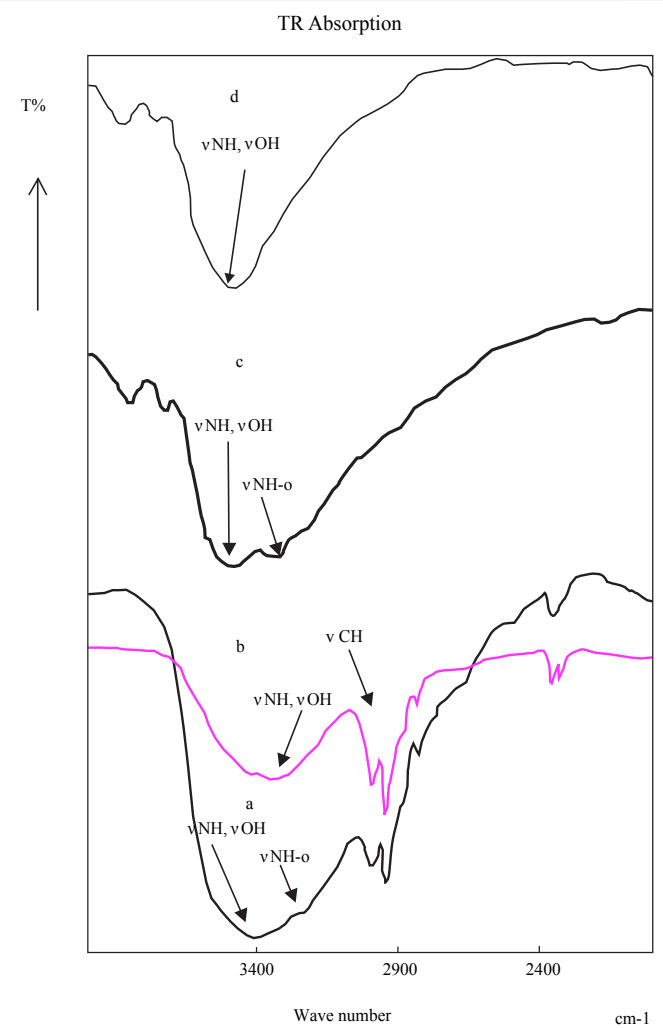

Figure 11: Infra-Red absorption spectra: a, DDMC/DNA complex; b, DDMC; c DEAE-dextran/DNA complex; d, DEAE-dextran. formation reaction should be different from that of DEAE-dextran because DDMC possesses a hydrophilic-hydrophobic micro-separated domain.

The Michaelis-Menten equation is commonly used for biological reactions such as enzyme reactions in which hydrophobic bonding and hydrogen bonding participate in complex formation. Simulations of DDMC complex formation reactions based on Michaelis-Menten equations have shown that DNA and DDMC complex formation produces a poly-ion complex, and a complex formation mechanism has been proposed in which hydrophobic bonding and hydrogen bonding participate in the complex formation process. It is thought that the DNA is condensed and thereby protected from intracellular decomposition by DNase and that this also facilitates transport through the nuclear membrane and into the nucleus. This transportation of the complex is facilitated by the hydrophobic bonding and hydrogen bonding of DDMC.

Figure 11 shows the infrared absorption spectra in the vicinity of wavelengths 1,900 to $3,900 \mathrm{~cm}^{-1}$ for the complexes formed by reactions between DNA and DDMC (graft ratio 100\%) or DEAE-dextran according to the procedures outlined in the Transfection Method section. For both DDMC and DEAE-dextran, their DNA complexes $(\mathrm{a}, \mathrm{c})$ showed hydrogen bond absorption due to the stretching vibrations of $\mathrm{N}-\mathrm{H}, \mathrm{O}-\mathrm{H}$, and $\mathrm{NH}-\mathrm{O}$ in the vicinity of $3400 \mathrm{~cm}^{-1}$, which are larger and broader than those in the respective starting substances $(\mathrm{b}, \mathrm{d})$. In addition, the $\mathrm{N}-\mathrm{H}$ and $\mathrm{O}-\mathrm{H}$ absorption spectra of the complexes $(\mathrm{a}, \mathrm{c})$ have shifted to the high-energy side compared to those in the respective starting substances $(\mathrm{b}, \mathrm{d})$.

This means that the intra-molecular hydrogen bonding interactions have become weak and that the complexes have been condensed by hydrophobic bonding. Although it was concluded that DDMC and DEAE-dextran have decreased entropy when bound to DNA compared with their unbound states, this is to be expected based on their stability with respect to outside stress. These results are thought to be due to the occurrence of steric alterations in each molecule. Of course, the high-energy shift is clearly larger for the DDMC/DNA complex. This intermolecular hydrogen bonding serves as a driving force for the folding of the complex into a neat steric structure, and Figure 11 shows the absorption spectrum of the $\mathrm{C}-\mathrm{H}$ stretch vibration in the vicinity of $3,000 \mathrm{~cm}^{-1}$ for DDMC, and this peak is broader in the DNA complex. The above results also demonstrate the occurrence of significant hydrophobic bonding in the DDMC/DNA complex.

\section{Cell transfection}

Cell transfection efficiency is said to be strongly dependent on DNA structure. DNA undergoes continuous coordinated changes from a swelled coil state to a condensed state (globule) when in solution, which is known as DNA condensation through a coil-globule transition, and the state of the DNA changes from ON to OFF[12]. This may induce discrete ON/OFF switching in transcriptional activity. From the standpoint of the transfection process, the condensation of DNA must be understood to represent the OFF state. Specifically, when the DNA is in a compact closed state, this aids its transport through the cell membrane and DNA decomposition inside the cell [14].

The important points for transfection are:

1) how the nucleic acid complex is efficiently taken into the cell [2]; 2) whether this suppresses the decomposition of DNA in the cytoplasm or endoplasmic reticulum; 3 ) how to bring about efficient release from the endoplasmic reticulum into the cytoplasm; 4) how to bring about efficient transport from the cytoplasm to the nucleus; and 5) ensuring 
Citation: Eshita Y, Higashihara J, Onishi M, Mizuno M, Yoshida J, et al. (2011) Mechanism of the Introduction of Exogenous Genes into Cultured Cells Using DEAE-Dextran-MMA Graft Copolymer as a Non-Viral Gene Carrier. II. Its Thixotropy Property. J Nanomedic Nanotechnol 2:105. doi:10.4172/2157-7439.1000105

Page 8 of 8

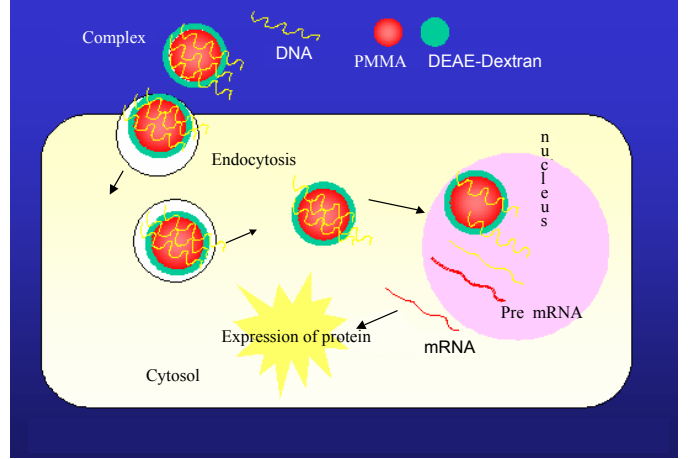

Figure 12: Schematic drawing of putative pathways for the delivery of foreign DNA in complex with DEAE-dextran-MMA graft copolymer.

the nucleic acid molecules are in a fit state to be transcribed in the nucleus.

However, the transfection of DNA using DDMC into cells is thought to depend on endocytosis (phagocytosis), which in turn depends on DNA and DDMC complex formation, meaning that the complex formation conditions are critical. This Michaelis-Menten type complex formation reaction is similar to the complexes formed between DNA and histones in vitro. With histone complexes, it is clear that DNA transcription depends on hydrophobic bonding alterations under the control of acetyl groups. In our case, it was also thought that the hydrophobicity of DDMC has a strong influence on DNA transcription, providing the environmental conditions are appropriate.

In addition, during cellular endocytosis, the PMMA portion, which is the hydrophobic domain of DDMC, is important for its transport through the cell membrane. The DNA and DDMC complex formation reaction is strongly influenced by $\mathrm{pH}$ and charge ratio, but electrostatic bonding also occurs between the negative charges of the phosphate esters of DNA and the positive charges of DDMC, and the complex is thus referred to as a poly-ion complex. Hydrophobic bonding and hydrogen bonding contribute to the formation of this complex, and the DNA is thus condensed and protected from decomposition by DNase inside the cell. It is also thought that the formation of this complex facilitates its transport through the nuclear membrane and into the nucleus [9]. Protection from decomposition in cells actually means protection from the actions of both DNase and dextransucrase, and it is thought that DDMC confers superior protection against these enzymes compared with DEAE-dextran, which is constituted from PIC bonds (simple electrostatic bonds). However, the extent to which DDMC is transported into cells is unclear, and future investigations are thus required. Figure 12 shows a schematic diagram of how DNA forms complexes with DDMC macromolecular micelles, how endocytosis occurs, and how the complex reaches the cell nucleus.

DDMC, which is used as a carrier for gene transfection, can be sterilized by autoclaving, which is not possible with other transfection reagents; has better transfection efficiency than DEAE-dextran alone; and is also thought to have low cellular toxicity. For these reasons, it is expected to be utilized for transfection experiments involving cells derived from arthropods and mammals in future studies.

\section{Acknowledgements}

A portion of this research was carried out with the support of a Japanese Ministry of Health, Labour, and Welfare Scientific Research Grant (H18-Shinko-Ippan-009 H20-Shinko-Ippan-015) and a Japanese Ministry of Education, Culture, Sports, Science, and Technology Scientific Research Grant (Basic C18580310, Basic B Overseas Science 20401050)

\section{References}

1. Hashida M (1995) Drug Delivery System - A New Challenge for Drug Discovery and Treatment. Kagaku-Dojin Publishing Co, Kyoto, Japan.

2. Sato T (2002) Carbohydrate Polymer for Gene Delivery. Kobunshi 51: 837-840

3. Onishi Y, Kikuchi Y (2003) Study of the Complex between DNA and DEAEdextran. Kobunshi Ronbunshu 60: 359-364.

4. Onishi Y, Kikuchi Y (2004) Study of the Complex between RNA and DEAEdextran. Kobunshi Ronbunshu 61: 139-143.

5. Onishi Y, Eshita Y, Murashita A, Mizuno M, Yoshida J (2005) Synthesis and Characterization of 2-Diethylaminoethyl(DEAE)-dextran-MMA Graft Copolymer for Non-viral Gene Delivery Vector. J Appl Polym Sci 98: 9-14.

6. Onishi Y, Eshita Y, Murashita A, Mizuno M, Yoshida J (2006) 2-Diethylaminoethyl(DEAE)-dextran-MMA Graft Copolymer for Non-viral Gene Delivery. Bull Res Cent Environ Sci Tech 5: 8-13.

7. Onishi Y, Eshita Y, Murashita A, Mizuno M, Yoshida J (2007) Characteristic of 2-Diethylaminoethyl(DEAE)-Dextran-MMA Graft Copolymer as a Non-viral Gene Carrier. Nanomedicine: Nanotech., Biol Med 3: 184-191.

8. Onishi Y, Eshita Y, Murashita A Mizuno M, Yoshida J (2008) A Novel Vector of 2-Diethylaminoethyl(DEAE)-Dextran-MMA Graft Copolymer for Non-Viral Gene Deliver. J Gene Med 10: 472

9. Eshita Y, Higashihara J, Onishi M, Mizuno M, Yoshida J, et al. (2009) Mechanism of Introduction of Exogenous Genes into Cultured Cells Using DEAE-DextranMMA Graft Copolymer as Non-Viral Gene Carrier. Molecules 14: 2669-2683.

10. Jorgenson L, Nielson HM (2009) Delivery Technologies for Biopharmaceuticals: DEAE-Dextran-MMA Graft Copolymer for Non-viral Delivery of DNA. John Wiley \& Sons, West Sussex, UK.

11. Karak N, Maliti S (1997) Dendritic Polymers: A Class of Novel Materials. J Polym Mater 14: 107-122.

12. Yoshikawa Y, Tsumoto K, Yoshikawa K (2002) Switching of Higher-order Structure of DNA and Gene Expression. Seibutsu Butsuri 42: 179-184.

13. Harashima H (2008) Quantitative Analysis of Transfection Efficiency between Viral and Non-viral Vectors. J Gene Med 10: 435-436.

14. Schreier JB (1969) Modification of Deoxyribonuclease Test Medium for Rapid identification of Serratia marcescens. Am J Clin Pathol 51: 711-716.

15. Yang YW, Yang JC (1997) Studies of DEAE-dextran-mediated Gene Transfer Biotechnol Appl Biochem 25: 47-51.

16. Ogris M, Steinlein P, Kursa M, Mechtler K, Kircheis R, Wagner E (1998) The Size of DNA/Transferrin-PEI Complexes is an Important Factor for Gene Expression in Cultured Cells. Gene Ther 5: 1425-1433. 